Article

\title{
Hostility toward Gender in Catholic and Political Right-Wing Movements
}

\author{
Ute Leimgruber(D)
}

Faculty of Catholic Theology, University of Regensburg, 93040 Regensburg, Germany; ute.leimgruber@ur.de

Received: 7 May 2020; Accepted: 18 June 2020; Published: 21 June 2020

check for updates

\begin{abstract}
Starting with a speech by Theodor Adorno, the essay analyzes some thematic parallels between political and religious populism regarding the view on gender and feminism. In both certain traditional Catholic circles and right-wing political parties, an explicit hostility toward gender can be observed. In this article, this resentment is discussed in three aspects: the defense of a traditional image of the family, the instrumentalization of women's rights against "the Islam", and, generally, the propaganda of anti-feminism or anti-genderism. Moreover, the text considers the fact that in spite of anti-feminist positions, many women are part of these movements, sometimes even as leaders. The text will prove that this is only a superficial contradiction. The right-wing populist groups-both secular and religious-promise to reduce the potential threat to modern societies while "preserving" the traditional order. The coalitions between them run along the lines of the "values" represented, including anti-feminism and anti-genderism. The danger that these "alliances" pose to a liberal society must not be underestimated by the religious and secular actors who value and protect ambiguity and diversity.
\end{abstract}

Keywords: religious populism; political populism; gender; anti-genderism; anti-feminism; religion and politics; right-wing Catholicism

\section{The Interconnectedness between Right-Wing Populism and Right-Wing Catholicism}

When Theodor W. Adorno's lecture "Aspects of the new right-wing radicalism"1 ("Aspekte des neuen Rechtsradikalismus") was published recently (Adorno 2019) ${ }^{2}$, there was some astonishment among commentators in German feuilletons: a phenomenon we are dealing with in the first decades of the new millennium to an alarming degree had already been described with farsightedness and clarity in the year 1967.

Adorno describes the structures of the radical right-wing system. Most of his analysis is still valid today. The lecture in which he outlined some characteristics of what he calls "right-wing radicalism" was given on 6 April, 1967 in Vienna. Some crucial aspects were published by himself in other, more fundamental texts (see Adorno 1973).

As a (female) Catholic theologian, I sympathize with some of Adorno's reflections. Large parts of the lecture can be read as a direct commentary on the current right-wing populisms: e.g., the "Alternative für Deutschland"/"Alternative for Germany" (AfD). In his descriptions of the system and its mechanisms, I recognize not only a wise statement, but also parallels to a current right-wing religious ideology and its methods. Some of the phenomena that Adorno refers to can be transferred precisely to the field of religious populism. Not without reason, Adorno also understood his own

\footnotetext{
1 All translations are mine [U.L.] or indicated otherwise. The original German quotations from Theodor Adorno are supplemented in the footnotes.

2 This specific lecture has not been published before.
} 
theory as a practical method for further critical thinking. The tricks of the right-wing populists are also mastered in the right-wing Catholic area-for example, in view of the fact that "they (...) in a certain way want the catastrophe"33 (Adorno 2019, p. 19).

One may observe this "unconscious desire for disaster"4 (Adorno 2019, p. 19) in the Catholic theological discourse, where forces are mobilized against liberalization by raising the specters of a looming division of the church (see, e.g., Honekamp 2019). Even the frequently used phrase of the "unity of the Catholic Church" is less theory-saturated than theological semantics suggest. This theorem is reminiscent of Adorno's description, who observes in the right-wing movements the phenomenon of balancing "the difference between real interests and the goals they pretend to pursue" ${ }^{\prime \prime}$ (Adorno 2019, p. 23).

What seems to be a matter of interest in ecclesiological unity on the surface often conceals the real aim of a unified, traditionalist order.

At this point, I do not want to make a detailed analysis of Adorno's theses with regard to Catholic populism. Far too seldom, however, religious populism is named as such and discussed in its interrelationship with political populism. The interactions at a structural level, especially in the gender discourse, are remarkable. Their interrelations are complex, as movements coincide in parts and are contradictory in others. My aim is to read religious and political right-wing movements together in this text and, especially from the perspective of gender, "pinpoint the tricks, (...) describe them precisely"6 (Adorno 2019, p. 54). As populism is not a natural disaster, one does not face it "as an observer": "how these things continue, and the responsibility for how they continue, is ultimately up to us $^{\prime \prime 7}$ (Adorno 2019, p. 55).

In the following, I use the terms "right-wing movements" and "right-wing populism" interchangeably. There are no consistent definitions for these terms, but certain key elements can be identified. Polarization and moralization are considered to be such fundamental dimensions of populism. On the one hand, there is a homogeneous, morally pure group (e.g., "the people") and, on the other hand, there are the opponents who are portrayed as immoral and dangerous (Priester 2017, p. 8; Müller 2016). In the political arena, new parties have emerged between conservative popular parties and the extreme right-wing fringe that are considered right-wing populist-in Germany, for example, the AfD (Priester 2017, p. 10). In the Catholic Church, an increasingly strong, extremely conservative group is playing a similar key role: e.g., Cardinal Gerhard Ludwig Müller (Müller 2020).

The theologian Magnus Striet diagnoses an ongoing "religious populism" ("Religionspopulismus") in "astonishing parallel" to political populism: "Working on the political field with the morally charged distinction category 'true people', one has to work with that of the 'true believers' on the religious field" (Striet 2019, p. 17). Religious populism is comparable to political populism: it is similarly anti-pluralistic and moralistic, it reduces complexity, and is ultimately ideological. Moreover, anti-intellectualism is one of the main features of both secular and religious populism (Striet 2019, p. 15). As Adorno said, "intellectuals are hated in particular. (...) these movements (...) turn against the bearers of the spirit. (...) The separation of so-called understanding and so-called feeling is (...) reified" ${ }^{8}$ (Adorno 2019, p. 33).

One of the most significant components is to insist on an "objective truth" and to regard oneself as defender of "the real (Christian/German/European, etc.) identity", which everyone could see by using "common sense" (which means you don't have to be intellectual).

\footnotetext{
... dass "sie (...) in gewisser Weise die Katastrophe wollen".

"unbewussten Wunsch nach Unheil".

"die Differenz zwischen realen Interessen und den vorgespiegelten Zielen".

"die Tricks dingfest [zu] machen, (...) sie genau [zu] beschreiben".

"Wie diese Dinge weitergehen und die Verantwortung dafür, wie sie weitergehen, das ist in letzter Instanz an uns".

"besonders verhasst [sind] die Intellektuellen. (...) diese Bewegungen ( . . ) wenden sich gegen die Träger des Geistes. (... ) Es wird (...) die Trennung von sogenanntem Verstand und sogenanntem Gefühl verdinglicht".
} 


\section{Ideological Overlaps in the Field of Anti-feminism}

The ideological power of right-wing propaganda is particularly evident in their relation to gender (Lang 2017a, 167ff; see also Roth and Dietze 2020). The hostility toward gender can be observed in both traditional Catholic circles and extreme right-wing political parties. The attempt to gain social influence by influencing the dominant discourses is evident. In both political and religious right-wing systems, a patriarchal and anti-feminist ideology is advocated, while, at the same time, women are presented as active parts of the movement. ${ }^{9}$ Concerning the content of this ideology, a large overlap can be detected. They may not be fighting in the same troops, but, regarding gender as a major threat, they are fighting for the same cause. Of course, there are differences: these become clear with regard to the value systems and ideas of order that are behind them. However, what is obvious as a common ground is summed up by Juliane Lang: "the focus on 'gender' as an omnipotent threat is presented as a difference between 'we' and 'the others' - in this case representatives of a traditional, strictly heteronormative gender order vs. the 'gender ideologues' (Kuby 2017) and a society shaped by 'genderism'” (Lang 2017a, p. 177). This narrative of a "morally good us" and "the morally bad others" with regard to gender can be found in secular as well as religious populisms.

In the following, I will examine three areas in particular in which right-wing parties and right-wing Catholicism act, if not hand in hand, then at least in the same direction: in the defense of a traditional image of the family, in the use of women's rights against the enemy image of "Islam", and, generally, through a position of anti-feminism or anti-genderism. At the same time, in view of such clearly anti-feminist positions, the question arises: isn't it a contradiction when women are part of these movements, sometimes even as leaders? The text will prove that this is only a superficial contradiction.

As will be shown in the conclusion, by regarding the so-called "gender ideology" as a major threat and by warning against subsequent dangers for the social and religious order, Catholic and secular populisms come together to form "unholy alliances" (Paternotte 2017, p. 135), even if church representatives explicitly distance themselves from right-wing parties (Wölki 2017, 181ff), and right-wing parties present themselves as anti-church (Bednarz 2019, p. 236). According to my analysis, disparate secular political and religious dispositions are unified by their hostility toward gender.

\subsection{Struggles for the "Natural Family"}

One of the ideological building blocks of right-wing populism is the image of the intact family and the complementary roles of men and women. As Elisa Gutsche notes, "the AfD represents a gender image that can be linked to ethnic ["völkisch"; orig.] and nationalist ideals. These images propagate a nationalist and patriarchal social order. Similar to the PiS and Fidesz-KDNP, these ideals focus on traditional families, i.e., the heterosexual relationship between the native man and the native woman and their children" (Gutsche 2019). In other words, this is the "biopolitical" (Foucault) coupling of gender policy with population policy (Kemper 2016, p. 149). Among right-wing conservatives, a tendency to devalue women and non-heterosexual people is more frequent, as well as the desire for unambiguity in connection with a traditional understanding of family and a cultural struggle against the "Zeitgeist" (Merle 2019, pp. 371-72). The religious, as well as the political right, share the stylization of the family as a place of traditional order, which can only be preserved on the basis of a binary gender understanding. Therefore, an ideological approach to the family is often combined with the warning against the decline of a Western or Christian culture. In other words, if certain institutions are to guarantee society and its continued existence-e.g., heteronormatively constructed marriage and family - the lowering of these norms is seen as a threat to society.

In Germany, the writings of the radical Catholic publicist Gabriele Kuby are well-known. She sees herself as an advocate of the Catholic "moral law" and takes action against gender studies and the

9 Although this article mainly focuses on Germany and on the Catholic Church, debates on "gender ideology" extend to Europe as well as Africa, Latin America, and the United States, and, of course, to other Christian Churches or evangelical groups. 
destruction of the family and the culture based on it in her view. Although Kuby's "texts blatantly contradict the propagated scientificness criteria" (Frey et al. 2014), her writings have had an enormous impact. Her book, "The Global Sexual Revolution—Destruction of Freedom in the Name of Freedom", has now been published in its sixth edition and has been translated into 17 languages. Her theses and publications are distributed in large parts of right-wing Catholic circles and are recommended as basic works for understanding "gender ideology". Kuby sees herself, together with other like-minded people, in the fight "for the truth of Christ" (Kuby 2017, p. 275), which was "objectively" recognizable. She refers to a biblical theology of creation in her argumentation in order to save the world from its downfall by "gender ideology".

The discourse on "gender ideology" has been emerging since the 1994 Cairo Conference on Population and Development and the 1995 Fourth World Conference on Women: Action for Equality, Development and Peace in Beijing. Theses conferences led to the official recognition of sexual and reproductive rights and to the embedding of the gender-mainstreaming strategy in the UN system. "These goals were opposed by the Holy See, which was defending the complementary of the sexes against the notion of gender. ( ... ) Gender was depicted as a strategic vehicle used by feminists and homosexual activists to attack and destabilize the 'natural' family" (Paternotte 2017, pp. 135-36). Pope John Paul II's theories of "the women" and "the body" postulate gender complementarity and a strictly binary system. The crucial document is Mulieris dignitatem (1988). Since John Paul II, every pope referred to "gender ideology" as family-destructive, insisting on the threats resulting from this "ideology". Joseph Ratzinger/Pope Benedikt XVI sees gender theories as a "revolution even against the biological guidelines"; for him, it is "a rebellion of human beings against the limits that they carry within themselves as biological beings. It is ultimately a rebellion against our God-given nature ["Geschöpflichkeit"]" (Ratzinger 1996, p. 142). In another context, he says: "the Church reaffirms her great 'yes' to the dignity and beauty of marriage as an expression of the faithful and generous bond between man and woman, and her no to 'gender' philosophies, because the reciprocity between male and female is an expression of the beauty of nature willed by the Creator" (Ratzinger 2013). Pope Francis has frequently reiterated his arguments against gender and reproductive rights on behalf of the traditional family. As shown by David Paternotte, so-called "'gender-ideology' is (... ) the name of a counterstrategy carefully designed by the head of the Church since the drawbacks of the UN conferences of Cairo and Beijing" (Paternotte 2017, p. 135). "Gender ideology" is a term that has detached itself from its Catholic origins and is now used in a whole range of secular right-wing populist groups. Combating gender is a priority for right-wing groups of every couleur.

While the Catholic Church has been fighting against "gender ideology" since 1995, the extreme right has been following these themes in Germany since the 2000s (Lang 2017a, p. 167). Catholic, as well as secular, right-wing groups represent simplistic nature-culture arguments to justify their own homogenous and traditionalist male-dominated world views and to defend their naturalistic anthropology and the "true Catholic values". These simplifications lead to a hermeneutic suspicion towards the liberal or gender-friendly sciences (Striet 2019, p. 22). The idealization of the mother's role in Catholic doctrine and the associated essentialization of the women's role should not be discussed in detail here. What is important in our context is that there are noteworthy thematic overlaps with right-wing populisms in their fight against modern gender-equitable (and non-heteronormative) family and sexual policies. "The concept of the enemy 'gender' is being discussed across political camps; topics of gender and family policy relevance act as a hinge between extreme, conservative and religious right-wingers with connections far into the bourgeois mainstream" (Lang 2017a, p. 174). The fight against women's reproductive rights, the right of access to contraception, impunity for abortion in certain circumstances, or medically assisted reproductive techniques are also linked to the defense of the traditionalist family image and concern for sexual morals. There are several religious organizations, some of which cooperate with one another and some of which have personnel links to political organizations - e.g., the pro-life organization "European Dignity Watch"—pursuing the goal to eradicate EU funding towards sexual and reproductive health and rights, led by Sophia Kuby, Gabriele Kuby's daughter. 
Furthermore, the pan-European, Christian extremist network "Agenda Europe", founded in 2013 ultimately aims at a fundamental de-liberalization in areas of marriage and family, life and equal treatment, and anti-discrimination legislation. Under the pretext of standing up for the "protection of life" and the "protection of the family" and aiming at the "restoration of natural order", "Agenda Europe" is directed against general women's rights and the rights of minorities-but in the name of all Christians (Datta 2018). Even though it is an extremist fringe group, it is supported by the Vatican, respectively, the Holy See, and finds coalitions even among moderate Catholic conservatives. A study by the European Union points out the dangers of "Agenda Europe" and clearly describes the interconnections of the political agenda with right-wing Catholic circles up to the Vatican: "Vatican surrogates catalysed the Christian, anti-SRR community in Europe and leveraged Catholic institutions to create a space where Agenda Europe members could discretely convene and strategize, away from public scrutiny, but under the helpful gaze of the Holy See" (Datta 2018, p. 19). Some of the arguments and assertions (which they themselves describe as extremist) are also supported by European bishops' conferences, or at least by a significant group of prominent bishops. With regard to family policy, decades of creating images of an enemy have shown success. Christian and secular groups have been able to introduce their ideological discourses into the field of family and gender politics at both a national and EU level. As shown by David Paternotte, "the development of gender studies as well as the concept of gender itself-that our social expectations based on biological sex are not innate but historically and socially contingent-and its inclusion in school programs have become the targets of conservative groups in France, Italy, Spain, Poland and Lithuania, provoking public debates and parliamentary discussions. These events are not disconnected moments of resistance, and scholars have emphasized the constant presence of the Catholic Church. The national church hierarchy is sometimes leading the mobilization (... ). More crucially, (...) these events are also connected on an ideological level. They must be regarded as national manifestations of a transnational mobilization against what is called 'gender ideology'" (Paternotte 2014, p. 2).

\subsection{Instrumentalizing Women's Rights: Anti-Islamism}

At first glance, the relationship to women's rights is contradictory among right-wing populist parties (Gutsche 2019). While officially advocating women's rights, right-wing populists adopt traditionalistic and anti-emancipatory opinions. At the same time, women's rights are instrumentalized in order to polemicize against Islam. As an example, this connection became apparent after the events surrounding New Year's Eve in Cologne 2015 ("Kölner Silvesternacht"). That evening, numerous women in Cologne were subjected to sexual harassment, committed predominantly by non-German men and migrants, many of them Muslims. The sexual violence was propagated by right-wing populists as part of the "migrant" or "Muslim culture". This led to a mobilization of feminism and women's rights by Islamophobic and xenophobic parties. Sabine Hark and Paula-Irene Villa call it the "ambivalent interconnections of racism, sexism and feminism in the present" (Hark and Villa 2018).

On the website of the AfD, the very first announcement under the headline "women's rights" reads: "More Islam in Germany runs counter to women's rights"10. The AfD warns against "the Islam", which is seen as opposing the equal status of men and women practiced in Germany and ensured by constitutional law.

The AfD makes itself the "protector" of women, whom it sees endangered by "the Islam" and comes to the cynical conclusion that in order to protect women and the constitutionally guaranteed society, modern feminism and value conservatism must be combined, which, in their own opinion, is best guaranteed by the AfD (Lang 2017b, p. 70).

Even if women's rights are rhetorically affirmed here, "feminism" is constructed as an elitist ideology and "gender" as a threat to "genuine femininity" (Mayer et al. 2018, p. 281). The AfD claims to protect a homogenous (folkish) culture through its fight against "Islamization" (unlike the "feminists"

10 https://afdkompakt.de/2020/02/10/mehr-islam-in-deutschland-laeuft-den-frauenrechten-zuwider/. 
and their "cultural relativism" and "gender delusion"). This can also be seen with regard to the roles of men and women in society.

Behind this reasoning is the fact that the position of women (and minorities) is seen as an indicator for the degree of being a modern and liberal society. Discourses revolving around gender roles, the role of women, and the relation of men and women have become sites of control and the power of interpretation in a society. Part of a restrictive asylum policy is to produce "German babies" (Gutsche 2019) in order to fight "foreign infiltration" by "the Islam". It is, therefore, no coincidence that right-wing populist politicians link the enemy images of anti-genderism and anti-Islamism. The framing is clear: both anti-genderism and anti-Islamism are a danger to "traditional values" and the society built on them.

Here, congruences between politics and the Church can also be observed: for example, by looking at certain statements made by Catholic dignitaries, who consider Christianity and human rights (which are viewed in a very Eurocentric manner) to be in danger from an increasing "Islamization". Along this line, the Holy See has warned that women's rights are endangered by "the Islam" and that marrying a Muslim may lead to an incapacitation of Christian women (Von Braun 2017, p. 33). In the document Erga migrantes caritas Christi, the Pontifical Council for the Pastoral Care of Migrants and Itinerant People (2004) advises against marriages between a Catholic and a Muslim because of "bitter experience" connected with the role of "the woman", who is "the least protected member of the Muslim family" (Nr. 67). A Catholic bishop pointed out that "Islam is by its theological nature the contradiction to Christianity" (Voderholzer 2018). He also considers the "danger of an impending Islamization of Central Europe (...) not entirely unrealistic"; a danger that is caused not by "warlike invasion and occupation, but by political asylum and fertility" (Voderholzer 2018). The argument of fertility-reasoning that Muslim women bear more children than non-Muslim women-is also common among political right-wing populist groups (Diefenbach 2018). It suggests that in the future, the majorities would be reversed, and strengthens the perception of "the Islam" as something to be feared, citing a gender dimension. The rhetorical fight against so called "Islamization" goes hand in hand with the instrumentalization of gender and women's rights-i.e., the protection of "the nation" or "Christianity" makes it necessary to protect the traditional family defined in heterosexual terms (Mayer et al. 2018, p. 281).

\subsection{Anti-Genderism and Anti-Feminism}

Both naturalizing the concept of gender and claiming the duality of gender are the bases of the right-wing groups' thinking in the political and religious field. In a sense, it does not work without the binary and essentialist gender gap. This also makes it clear that the struggle for the "family" as a traditional panel of values is only a fight for the tip of the iceberg. In contrast to the opinion that the right-wing groups had not understood the gender concept, it should be clear: they do know what the concept "gender" is all about (Hark and Villa 2017, p. 8). This concept negates the premise of an unchangeable duality and natural essence of gender relations-and, in a certain sense, calls into question the entire order of right-wing formations based on heterogeneity, immutability, and uniformity. The right-catholic biblical "naturalness" relies on the determinism of bipolarity and gender complementarity - and uses it as a fact to campaign against the denaturalization of the traditional gender order and the putative representatives of this position. As Juliane Lang observes, "designs of masculinity/ies and femininity/ies are functional for the internal cohesion of the community. (...) Gender becomes the central identity-creating category" (Lang 2017a, p. 169). In the Catholic Church, large parts of the conservative systematic theology are bound to the binary gender concept, so that gender studies, as well as political instruments, such as gender mainstreaming, are denounced as main opponents of the "true" or "natural" order. Gender has become-in the words of Adorno, who speaks with regard to communism - "a frightening slogan, [ ... ] detached from any knowledge of the issue"11 (Adorno 2019, p. 31).

11 "zu einem Schreckwort geworden”, “abgespalten von jeder Kenntnis der Sache”. 
On this basis, it is understandable why gender studies, gender mainstreaming, and all those who stand up for it—in short, "feminists" - are the favorite enemies of all right-wing groups. Gender studies are described as ideological; they are even denied to be scientific. Some go even further and use terms such as "gender madness" ("Gender-Wahnsinn") or "gender gaga" (Kelle 2015). This semantic framing suggests that the proponents of gender theories are not capable of understanding and not to be taken seriously-in contrast to those who judge them. With this not only rational but also moral devaluation, one thing becomes clear: the right-wing movements have realized what the term "gender" stands for, and it is no coincidence that they adopt this defensive, pejorative "anti-attitude". The concept of gender is connected with the struggle for a diverse and plural world view that approves of complex dynamics and ambiguities and seeks to negotiate cultural, political, and social roles. There is no doubt that a world view that moves beyond rigid, natural definitions-not only of men and women, but, ultimately, of all people-must be stylized as an enemy image.

Here, overlaps between sexism and racism become evident once again: both of them are based on the natural, essentialist definition of members of certain groups-i.e., gender or race; the pattern of argumentation are the same in both cases, where women have to fit certain norms because of their "nature" and people of other origins are expected to act in the same way. This "authoritarian attitude (...) claims for itself an infallible knowledge of what is and what should be, (...) a power of definition of what life may and may not be lived" (Maihofer and Schutzbach 2017, p. 214). An example of racist naturalism is the "Identitäre Bewegung" ("Identitarian Movement"). Their Islamophobic and racist positions are based on the so-called "ethnopluralism": i.e., their aim is to maintain the existence of individual peoples or ethnic groups, whose cultural characteristics they regard as threatened by the blending of different peoples. From this position, they justify a strict separation of the ethnic groups: each people should live exclusively on "its own territory" and, in this way preserve, its "identity". Gender theories, as well as a liberal attitude towards migration, imply a certain mobility or flexibility - both categories that are rejected by right-wing populists.

As far as the discussion in the Catholic-theological right-wing spectrum is concerned, the following reasoning can be observed: according to the protagonists, the "biological facts" are not only perceivable to the "common sense" (Müller 2016), but they are positively given in the first book of the Bible/first book of Moses (Genesis), and, thus, they are part of the divine revelation. This is why, in this opinion, there is no need for a discussion about reforms or changes; in fact, there should not be one at all, because a change would be against the declared will of God (see Müller 2020). With these arguments, the represented positions put themselves out of reach of any criticism, not only with regard to the conception of what is to be a human, but also in the field of ecclesiology, Christology, sacraments' theology, or ministry. The binary, essentialist understanding of gender is not to be underestimated as simply argumentative or (in Adorno's sense) propagandistic support for this kind of theology; rather, it is claimed as condition sine qua non for the correct, "true", and, thus, only "Catholic" way of doing theology resp. believing. If the "sacramental structure" of the church is only conceivable under the precondition of an essentialist gender complementarity, the own identity would be a trial with a flexibilization and de-essentialization of the concept of gender. Anti-genderism is part of the right-wing populist struggle for an ideologically founded homogenization of society, as well as for a uniformly understood unitary Catholicism ("uniformiert verstandener Einheitskatholizismus"). It is about a very specific world view and a comprehensive social order is at stake, and anti-feminism is the "cipher used to legitimize anti-egalitarian world views in the middle of society" (Schutzbach 2020, p. 5).

The anti-feminist attitudes of right-wing populists correspond to a broad-based patriarchal system that uses misogynous forms of expression (see Manne 2018). Even if extreme political positions are not shared by the majority of the population, anti-feminism and anti-gender discourses are widespread. Biologistic views on how women (and men) supposedly tick are widely accepted without much contradiction. Kate Manne (Manne 2018) diagnoses a broad misogynous attitude towards women, which becomes especially apparent when they reject patriarchal claims. The danger here is that the propagandistic discourse on "gender ideology" or "gender dictatorship" makes right-wing populism, with its dangerous mechanisms and hatred towards minorities, connectable on a broad scale. 


\section{Contradiction Only at First Sight: Women in Right-Wing Movements}

Political and religious right-wing populisms can, therefore, be compared with each other or be treated similarly. Of course, there are differences, but they do not contradict the thesis that in certain aspects, both phenomena resemble each other strongly. In both populist views, understanding gender in a binary way plays an important role in legitimating one's own way of thinking. Despite the obvious patriarchal and anti-feminist agenda, however, there are many women in important positions or functions. At the same time, both the political and the religious populist movements have a large number of female supporters or voters.

Prima facie, the situation seems to be contradictory. Women take responsibility as representatives of a misogynous system and even demonstrate in public for the anti-feminist agenda (e.g., "Maria 1.0"; see Michelt 2019). For these women, this doesn't lead to confusion. The traditionalist, anti-feminist attitude is not a generalized misogyny. On the contrary, women who comply with the heteronormative guidelines and accept the traditional, stereotype male-female roles without opposing them are even appreciated in patriarchally organized societies (see Manne 2018, p. 192). This will be examined in the following chapter with regard to visible representatives and invisible supporters (e.g., female voters).

\subsection{Women in Leadership Positions}

It can be observed that even in systems that represent a decidedly patriarchal, anti-feminist world view, women appear as leaders: e.g., Marine LePen in France (FN) or Alice Weidel in Germany (AfD). In the religious field, there are also several public and enthusiastic supporters of the system: e.g., Gabriele Kuby. It is part of the self-presentation of these groups that the careers of such women (such as Alice Weidel or Beatrix von Storch) show that a party such as the AfD is not misogynistic, otherwise these women would not have been attained such high positions (see Radvan 2015, p. 242). A similar approach is taken in the religious context, when the group Maria 1.0 is cited as evidence for the woman-friendliness of the Catholic Church system (also by women themselves: see Schmidt 2020). However, neither the many female supporters of the Catholic Church nor the women in the political right-wing movements are an argument for the allegedly predominant gender justice, for a broad appreciation of women, or for a corresponding "modern" image of women in these groups. The fact that women publicly and vehemently support right-wing populist movements does not contradict the anti-feminist sediment of these ideologies. The visibility of women in the right-wing spectrum is only a superficial demonstration of "equality" - actually, it is an illusion. The program and structures are clearly patriarchal-i.e., based on male leadership and dominance. At the same time, a woman in a male-coded position can be used as a kind of camouflage to disguise their own interests and make themselves more amenable to society as a whole. Who wants to admit in public that the ideas of their own group are clearly anti-feminist or patriarchal? Women can also have some kind of alibi function (tokenism) in these groups; they represent all "women", but as an "exception to the rule" by which they are measured. Thus, if the rule is "motherhood" and "family devotion", the rule is confirmed by the few exceptions and the female tokens are still accepted as "good women" as long as they do not explicitly oppose the basic ideology. Gayatri Chakravorty Spivak reflects this phenomenon of tokenism from the perspective of a female scientist of color (Spivak 1987, 103ff). She remarks that dominant groups tolerate a few marginalized people in the center, but accept them only insofar as they confirm the ideology of the dominant group-i.e., hold the same opinion as the leaders. "The putative center welcomes selective inhabitants of the margin in order better to exclude the margin. And it is the center that offers the official explanation" (Spivak 1987, p. 107). For the women affected, tokenism means higher visibility, but also the reproduction of universal exclusion. Women such as Alice Weidel are aware of their prominent, distinct visibility and use it to good effect. At the same time, they promote the exclusion of women on a broad social level. There is only an apparent contradiction between the ideology of motherhood, including caring norms and women's concrete life constellations (also in the private sphere), so the fact that Alice Weidel is married to a woman, raising two adopted sons together with her and at the same time representing the traditionalist world view of the AfD in the forefront as 
the leader of the opposition in the German parliament or as the chairwoman of the regional association of the AfD in Baden-Württemberg could be seen as a contradiction from the outside. Even though private life and the apparent contradiction between an openly lived lesbian lifestyle in combination with a leading position as a woman and a rather homophobic, anti-feminist position within the AfD is not addressed by her, it is still remarkable (Siri 2017, p. 163). On a second glance, this contradiction is not a real contradiction: Alice Weidel refrains from expressing a dissent to the ideology or the system based on her situation as a lesbian woman. She is the exception, which nevertheless supports the patriarchal fundaments and is tolerated by the men, for it, or even receives acknowledgement. The benefit is twofold: the party wins because it can "prove" its own women-friendliness with token women such as Alice Weidel. Alice Weidel benefits from this because she is one of very few women who is particularly visible, because she is obviously not considered "anti-feminist" or misogynistic (or homophobic) because of her private situation, and, therefore, has special authority when she makes party political statements in this regard.

The same may equally apply to some women in right-wing Catholic circles-e.g., the already mentioned Gabriele Kuby or Gloria von Thurn und Taxis, a figurehead of these circles with excellent connections to far-right politicians, such as Steve Bannon, as well as to conservative church leaders, such as Cardinal Gerhard Ludwig Müller. Women who are active in the right-wing groups represent very conservative, family-traditionalist, even fundamentalist positions, which are not least directed against their own interests of independence or equal dignity. These women represent racist and misogynistic resentments; they support and uphold anti-feministic positions, sometimes overtly and visibly, and sometimes implicitly and certainly not always intentionally. In her book, "Down Girl", Kate Manne provides a plausible explanation as to why women in misogynous systems and against the background of sexist or anti-feminist ideologies may accept the prevailing gender roles and even gain power in an apparently contradictory manner: "women's power will be better tolerated when it's wielded in service of patriarchal interests, for example, conservative and right-wing 'family-orientated' political movements. This is plausibly borne out by the last several decades of women in the right faring comparatively well in positions of leadership" (Manne 2018, p. 115). A number of women themselves hold strictly conservative or even racist views. They have an interest in supporting and maintaining the patriarchal system, also, because they benefit from it. They receive positive attention and confirmation and can take a supposedly male-dominated place, but without questioning the dominant gender hierarchies.

\subsection{Women's Support in Catering for Women's Practical Gender Interests}

At the same time, the right-wing populist parties try to give women moral recognition in case of support: i.e., to let them know that they are the "good women" (Manne 2018, p. 192). The profit promised to women can also be very concrete: for example, from a monetary point of view. The two Polish authors, Weronika Grzebalska and Elena Zacharenko, have published a comparative European study, "Triumph of the Women? The Female Face of the Far Right in Europe" (Grzebalska and Zacharenko 2018; see Gutsche 2018), in which they have developed the theory that right-wing populists primarily address practical gender-related interests of women with their policies, but not strategic gender interests. This means that the concrete conditions of women are being supported within traditional family policy. The study shows that the Polish party "Prawo i Sprawiedliwość"/"Law and Justice" (PiS) supports women in the context of the gender-based separation of labor: i.e., in care activities in the household and in bringing up children. "Immediately after taking office, the PiS launched the 'Family 500+' programme, which grants families from the second child up to the age of 18 an unconditional monthly transfer payment of about 120 euros. This programme represents the largest redistribution programme in Poland since 1989, has significantly reduced poverty among families with children and is viewed positively by the majority of society. In addition, PiS has introduced a one-off payment of 1000 euros for women who give birth to a terminally ill or severely disabled child" (Gutsche 2019). As far as these practical gender interests are concerned, it is a win-win situation in a certain sense: women 
are benefiting, and the party secures the loyalty of women. The AfD in Germany is also trying to follow this course by catering to women's practical gender interests to secure the support of women (especially in traditional livelihoods). In its programs, it demands similar transfer payments, as the PiS has already realized in Poland. One problematic aspect of this is that the promotion of women's practical interests is aimed only at those life situations that are in line with the party's political agenda, which is strictly heteronormative and traditional (Lang 2017b, p. 63; see also Kemper 2016). Political support measures should only be targeting mothers; extra-familial care is acceptable merely as an exception: "the ideal place for a small child is on mummy's lap". ${ }^{12}$ The demands include tax relief or financial transfer payments for German families with many children. Juliane Lang calls this "family populism" (Lang 2017b, p. 63). Furthermore, the AfD wants to massively restrict the reproductive rights of women. Beatrix von Storch, a member of the German Parliament, for example, is an important player in the international "life protection movement" ("Lebensschutzbewegung")—-the connection to certain positions within the Catholic Church again is obvious. Thus, if the question is raised why women support right-wing populist groups, one must also take into account concrete family and social policies and the concrete profit of women or families (Gutsche 2019) who, in view of the widespread fear of social decline and within a traditional division of labor, do not feel addressed by the traditional parties, or who see themselves as traditionally Catholic and find these values reflected in populist parties.

\section{Conclusions}

This essay aims to contribute to the wider discussion on gender and populism. The right-wing populist groups - both secular and religious—-promise to reduce the potential threat to modern societies while "preserving" or "restoring" the traditional, proper order. This is where coalitions between right-wing political and right-wing religious circles can be detected: the lines of distinction run along the "values" represented, including anti-feminism and anti-genderism. In certain Catholic circles, it seems to be more important to fight against abortion and/or "gender-ideology" than to believe in God: even explicit atheists are included as supporters in their propaganda, if it supports their own world view. Thus, the declared atheist and evolutionary biologist Ulrich Kutschera is also willing to help right-wing Catholic circles in their common fight against "gender-ideology". ${ }^{13}$

As Sonja Strube shows, for more than 20 years, "cooperation between politically explicit (new) right-wing media ( ... ) and individuals and groups with a fundamentalist reactionary Christian self-concept ( . . . )" can be observed (Strube 2017b, p. 15; see also Strube 2013, 2017a). In this article, I am interested in the role of "gender" in these unholy alliances, which are formed partly explicitly and in terms of personal topics (e.g., "protection of life", Ulrich Kutschera), partly in dealing with the same gender-related topics (e.g., family, abortion), and partly through a similar semantic framing (e.g., "ideology", "danger", etc.). It is important to analyze these alliances from a gender perspective, because this is the crucial point at which right-wing populisms are particularly well connected to the center of society.

Populisms tend to lean towards a traditional, patriarchal order in which "othering" forms part of the core narrative. The "others", who stand for plurality or diversity, are excluded and downgraded. It is not a narrative that considers gender justice and a change in patriarchal structures as one of its contents. The indispensable basis of this world view is a heteronomous, binary gender system; de-essentialization is strictly condemned. The fight against "gender" is made into a question of survival for the whole culture. Right-wing populist groups in the Catholic Church instrumentalize the Bible by referring to the history of creation (genesis) or Jesus' "founder's will" to represent their own agenda, and they do so with the methods that Adorno accurately described for right-wing extremism.

It is evident that the topic is highly complex and multilayered. Cardinal Wölki (Cologne) has unmistakably distanced himself from right-wing populist parties, such as the AfD. Furthermore, among

$\begin{array}{ll}12 & \text { https://afd.nrw/beschluesse-des-landesverbands-zur-programmatik/2014/04/grundpositionen-zum-thema-familie/. } \\ 13 & \text { https://www.kath.net/news/60177. }\end{array}$ 
Catholics, only a few show an affinity to right-wing populist parties or to the right-wing Catholic fringe groups (Püttmann 2017, 49f), but there is a high level of agreement with anti-feminist tendencies among both leaders and believers. Many conservative Catholics represent traditional family values and, in their majority, also, an essentialist, binary gender pattern. Women are seen as experts in care, nurturing, compassion, and attention. The fact that the right-wing can connect to these positions or how they deal with them and use them in their own interest is seen as quite dangerous (Bednarz 2019; see also Kuhar and Paternotte 2017). In the simplistic populist discourse, anti-feminist and sometimes racist, but always essentialist, positions are held, which are not compatible with modern scientific theology. Reflection, as well as critical research, is disavowed as "relativist" or "modernist". The abbreviated talk of unity and unambiguity obstructs a differentiated perspective (Striet 2019, p. 16).

Research findings of the human sciences are resented or cited fragmentarily to "prove" one's own position of a God-given and unchangeable binary gender order. The insights of the theological sciences are either doubted in its validity or instrumentalized for its own position (see Striet 2019, p. 22; see also Goertz 2015). Adorno points out, "that by no means all elements of this ideology are untrue, but that (...) truth is put into the service of untruth"14 (Adorno 2019, p. 39). In the Catholic Church, this often happens with the use of the term "(new) evangelization", which, in the end, is rather used as a strategy to achieve one's own goals. By this reference to the Gospel, criticism is clearly made more difficult, or the "true faith" of the critics is denied or doubted. Anti-feminist religious populism is anything but a harmless fringe group in the coalition with political right-wing populisms, for at their core, they form an opposition to liberal society and its ambiguities and pluralistic assumptions.

Funding: This research received no external funding.

Conflicts of Interest: The author declares no conflict of interest.

\section{References}

Adorno, Theodor W. 1973. Studien zum autoritären Charakter. Frankfurt am Main: Suhrkamp.

Adorno, Theodor W. 2019. Aspekte des neuen Rechtsradikalismus. Berlin: Suhrkamp.

Bednarz, Liane. 2019. Die Angstprediger. Wie rechte Christen Gesellschaft und Kirchen unterwandern. Bonn: bpb.

Datta, Neil. 2018. "Restoring the Natural Order": The Religious Extremists' Vision to Mobilize European Societies against Human Rights on Sexuality and Reproduction. Secretary of the European Parliamentary Forum on Population and Development (EPF). Available online: https://www.epfweb.org/sites/epfweb.org/files/rtno_ epf_book_lores.pdf (accessed on 19 June 2020).

Diefenbach, Aletta. 2018. Von "Abendland", "Islamisierung" und "Ignoranz": Wie der rechtspopulistische Mobilisierungsdiskurs Angst erzeugt. In: Affective Societies Blog. Impulse aus der Forschung. Freie Universität Berlin. Available online: http://affective-societies.de/2018/aus-der-forschung/von-abendlandislamisierung-und-ignoranz-wie-der-rechtspopulistische-mobilisierungsdiskurs-angst-erzeugt/ (accessed on 19 June 2020).

Frey, Regina, Marc Gärtner, Manfred Köhnen, and Sebastian Scheele. 2014. Gender, Scientificness and Ideology. Edited by the Heinrich Böll Foundation. Available online: https://www.gwi-boell.de/sites/default/files/ gender_scientificness_and_ideology.pdf (accessed on 19 June 2020).

Goertz, Stephan. 2015. "Wer bin ich ihn zu verurteilen?". Homosexualität und katholische Kirche. Freiburg: Herder.

Grzebalska, Weronika, and Elena Zacharenko. 2018. Country Case Study Poland. In Triumph of the Women? The Female Face of the Far and Populist Right in Europe. Edited by Elisa Gutsche. Berlin: Friedrich-Ebert-Stiftung, pp. 80-91. Available online: http://library.fes.de/pdf-files/dialog/14636.pdf (accessed on 19 June 2020).

Gutsche, Elisa, ed. 2018. Triumph of the Women? The Female Face of the Far and Populist Right in Europe. Berlin: FriedrichEbert-Stiftung, Available online: http://library.fes.de/pdf-files/dialog/14636.pdf (accessed on 19 June 2020).

14 “dass keineswegs alle Elemente dieser Ideologie unwahr sind, sondern dass (...) die Wahrheit in den Dienst der Unwahrheit gestellt wird". 
Gutsche, Elisa. 2019. Das weibliche Gesicht der Rechten. Europa stärken. Frankfurter Hefte 5/2019. pp. 11-14. Available online: https://www.frankfurter-hefte.de/artikel/das-weibliche-gesicht-der-rechten-2682/ (accessed on 19 June 2020).

Hark, Sabine, and Paula-Irene Villa, eds. 2017. Anti-Genderismus. Sexualität und Geschlecht als Schauplätze internationaler Auseinandersetzungen, 2nd ed.; Bielefeld: Transcript.

Hark, Sabine, and Paula-Irene Villa. 2018. Unterscheiden und herrschen. Ein Essay zu den ambivalenten Verflechtungen von Rassismus, Seximus und Feminismus in der Gegenwart, 2nd ed.; Bielefeld: Transcript.

Honekamp, Felix. 2019. Die katholische Kirche in Gefahr. Available online: https://www.kath.net/news/69194 (accessed on 19 June 2020).

Kelle, Birgit. 2015. GenderGaga: Wie eine absurde Ideologie unseren Alltag erobern will. Dillerberg: Adeo.

Kemper, Andreas. 2016. Geschlechter- und familienpolitische Positionen der AfD. In Kulturkampf von Rechts. AfD, Pegida und die Neue Rechte. Edited by Helmut Kellershohn and Wolfgang Kastrup. Münster: Unrast, pp. 147-61.

Kuby, Gabriele. 2017. Die Revolution. Zerstörung der Freiheit im Namen der Freiheit, 6th ed. Kisslegg: fe-Medienverlag.

Kuhar, Roman, and David Paternotte, eds. 2017. Anti-Gender Campaigns in Europe-Mobilizing against Equality. London and New York: Rowman \& Littlefield.

Lang, Juliane. 2017a. Familie und Vaterland in der Krise. Der extreme rechte Diskurs um Gender. In Anti-Genderismus. Sexualität und Geschlecht als Schauplätze internationaler Auseinandersetzungen, 2nd ed.; Edited by Sabine Hark and Paula-Irene Villa. Bielefeld: Transcript, pp. 167-81.

Lang, Juliane. 2017b. Feindbild Feminismus. Familien- und Geschlechterpolitik in der AfD. In AfD und FPÖ. Antisemitismus, Völkischer Nationalismus und Geschlechterbilder. Edited by Stephan Grigat. Baden-Baden: Nomos, pp. 61-78.

Maihofer, Andrea, and Franziska Schutzbach. 2017. Vom Antifeminismus zum 'Anti-Genderismus'. Eine zeitdiagnostische Betrachtung am Beispiel Schweiz. In Anti-Genderismus. Sexualität und Geschlecht als Schauplätze internationaler Auseinandersetzungen, 2nd ed.; Edited by Sabine Hark and Paula-Irene Villa. Bielefeld: Transcript, pp. 201-17.

Manne, Kate. 2018. Down Girl. The Logic of Misogyny. Oxford: Oxford University Press.

Mayer, Stefanie, Iztok Šori, Birgit Sauer, and Edma Ajanović. 2018. Mann, Frau, Volk. Familienidylle, Heteronormativität und Femonationalismus im europäischen rechten Populismus. Feministische Studien 36: 269-85. [CrossRef]

Merle, Kristin. 2019. Religion in der Öffentlichkeit. Digitalisierung als Herausforderung für kirchliche Kommunikationskulturen. Berlin and Boston: De Gruyter.

Michelt, Viktoria. 2019. Initiative Maria 1.0: "Die Gottesmutter braucht kein Update". Available online: https://www.vaticannews.va/de/kirche/news/2019-07/maria-bewegung-deutschland-gleichberechtigungupdate.html (accessed on 19 June 2020).

Müller, Jan-Werner. 2016. Populismus. Symptom einer Krise der politischen Repräsentation? Aus Politik und Zeitgeschichte 66: 40-42. Available online: https://www.bpb.de/apuz/234701/populismus-symptom-einerkrise-der-politischen-repraesentation (accessed on 19 June 2020).

Müller, Gerhard-Ludwig. 2020. “Das Gift, das die Kirche lähmt”. Neujahrspredigt im Rahmen einer Konferenz der Fellowship of Catholic University Students (FOCUS). Phoenix. Available online: https://de.catholicnewsagency. com/story/kardinal-muller-kirchenfursten-lechzen-nach-einer-zivilreligion-ohne-sakramente-5548 (accessed on 19 June 2020).

Paternotte, David. 2014. Christian Trouble: The Catholic Church and the Subversion of Gender. CritCom: A Forum for Research \& Commentary on Europe. Available online: https://is.muni.cz/el/1423/jaro2017/GEN184/ um/Paternotte_2014.pdf (accessed on 19 June 2020).

Paternotte, David. 2017. Blessing the Crowds. Catholic Mobilisations against Gender in Europe. In Anti-Genderismus. Sexualität und Geschlecht als Schauplätze internationaler Auseinandersetzungen, 2nd ed.; Edited by Sabine Hark and Paula-Irene Villa. Bielefeld: Transcript, pp. 129-48.

Pontifical Council for the Pastoral Care of Migrants and Itinerant People. 2004. Erga Migrantes Caritas Christi (The Love of Christ towards Migrants). Available online: http://ottezme.net/roman_curia/pontifical_councils/ migrants/documents/rc_pc_migrants_doc_20040514_erga-migrantes-caritas-christi_en.html (accessed on 19 June 2020).

Priester, Karin. 2017. Das Syndrom des Populismus. Dossier Rechtspopulismus. Edited by Bundeszentrale für Politische Bildung bpb. pp. 7-12. Available online: https://www.bpb.de/politik/extremismus/rechtspopulismus/241385/ was-heisst-rechtspopulismus (accessed on 19 June 2020). 
Püttmann, Andreas. 2017. Was ist die AfD? Und wie als Kirche mit ihr umgehen? In AfD, Pegida und Co. Angriff auf die Religion? Edited by Stefan Orth and Volker Resing. Freiburg: Herder, pp. 36-57.

Radvan, Heike. 2015. Prävention von Rechtsextremismus unter Berücksichtigung von Genderperspektiven. In Dominanzkultur Reloaded. Neue Texte zu gesellschaftlichen Machtverhältnissen und ihren Wechselwirkungen; Edited by Iman Attia, Swantje Köbsell and Nivedita Prasad. Bielefeld: Transcript, pp. 241-54.

Ratzinger, Joseph. 1996. Salz der Erde. Christentum und katholische Kirche an der Jahrtausendwende. Ein Gespräch mit Peter Seewald. Stuttgart: Deutsche Verlags-Anstalt.

Ratzinger, Joseph/Benedikt, XVI. 2013. Address of his holiness pope Benedict XVI to participants in the plenary meeting of the pontifical council "cor unum" (Ansprache von Papst Benedikt XVI. An die Teilnehmer der Vollversammlung des päpstlichen Rates "cor unum").

Roth, Julia, and Gabriele Dietze. 2020. Right-Wing Populism and Gender. European Perspectives and beyond; Bielefeld: Transcript.

Schmidt, Dorothea. 2020. Tagebuch zum Synodalen Weg. Available online: https://mariaeinspunktnull.de/docs/ Tagebuch_Schmidt_ErsteSynodalversammlung.pdf (accessed on 19 June 2020).

Schutzbach, Franziska. 2020. Frau als Feind. Süddeutsche Zeitung, February 5.

Siri, Jasmin. 2017. Rechte Frauen. Ein Blick hinter unsichtbare Fassaden. In Kursbuch 192 Frauen II. Edited by Armin Nassehi and Peter Felixberger. Hamburg: Murmann Publishers, pp. 152-66.

Spivak, Gayatri Chakravorty. 1987. Explanation and Culture: Marginalia. In Other Worlds: Essays in Cultural Politics. London: Routledge, pp. 103-17.

Striet, Magnus. 2019. Einfach nur glauben? Ein Plädoyer für Komplexitätsresilienz statt -reduktion. In Die Komplexität der Welt und die Sehnsucht nach Einfachheit (Salzburger Hochschulwochen 2019). Edited by Martin Dürnberger. Innsbruck and Wien: Tyrolia, pp. 9-28.

Strube, Sonja Angelika. 2013. Rechtsextremen Tendenzen begegnen. Handreichung für Gemeindearbeit und kirchliche Erwachsenenbildung. Freiburg: Herder.

Strube, Sonja Angelika. 2017a. Christliche Unterstützer der AfD. Milieus, Schnittmengen, Allianzen. In AfD, Pegida und Co. Angriff auf die Religion? Edited by Stefan Orth and Volker Resing. Freiburg: Herder, pp. 58-71.

Strube, Sonja Angelika. 2017b. Wie Theologie Gruppenbezogener Menschenfeindlichkeit entgegenwirken kann. Erreichtes und Desiderate. In Das Fremde akzeptieren. Gruppenbezogener Menschenfeindlichkeit entgegenwirken. Theologische Ansätze. Edited by Dies. Freiburg: Herder, pp. 13-29.

Voderholzer, Rudolf. 2018. Predigt zur Pontifikalmesse bei der 59. Gelöbniswallfahrt der Donauschwaben in Altötting. Available online: https://www.kath.net/news/64420 (accessed on 19 June 2020).

Von Braun, Christina. 2017. Anti-Genderismus. Über das Feindbild Geschlechterforschung. In Kursbuch 192 Frauen II. Edited by Armin Nassehi and Peter Felixberger. Hamburg: Murmann Publishers, pp. 28-45.

Wölki, Rainer Maria. 2017. Entschieden für Menschenwürde und Menschenrechte. Zur kirchlichen Haltung gegen Rechtspopulismus. In AfD, Pegida und Co. Angriff auf die Religion? Edited by Stefan Orth and Volker Resing. Freiburg: Herder, pp. 181-90.

(C) 2020 by the author. Licensee MDPI, Basel, Switzerland. This article is an open access article distributed under the terms and conditions of the Creative Commons Attribution (CC BY) license (http://creativecommons.org/licenses/by/4.0/). 